IP Periodica Polytechnica

Transportation Engineering

46(4), pp. 185-193, 2018

https://doi.org/10.3311/PPtr. 11708

Creative Commons Attribution (i)

RESEARCH ARTICLE

\section{An overview of Natural Gas Use in Ships: Necessity and Engine Supply}

\author{
Justas Žaglinskis ${ }^{1 *}$, Paulius Rapalis ${ }^{2}$, Nadezda Lazareva ${ }^{3}$
}

Received 28 March 2017; accepted 13 November 2017

\begin{abstract}
The article consists of analysis of existing and planned air pollution from ships control and prevention tools such Marpol 73/78 Annex VI, Energy Efficiency Design Index, Energy efficiency operational indicator, Ship energy efficiency management plan, Regulation on the Monitoring Reporting and Verification of shipping emissions, Carbon tax, Maritime emission trading scheme. Norms of these control and prevention tools are difficult to ensue using traditional marine fuels. Pollution rates getting tighter and alternatives have to be used, and some of them have long been known and are not widely used due to objective reasons. Such alternative is natural gas, and its use in ship power plants could reduce concentrations of nitrogen, sulphur, carbon compounds and other pollutants in engine exhaust gas up to acceptable level. The part of maritime sector choosing gas or dual-fuel engines due to tighter pollution rates, and the supply of these engines analyzed in last part of article.
\end{abstract}

\section{Keywords}

Marpol 73/78, non-road engines, natural gas engines, dualfuel engines, engine market, $L N G$

\footnotetext{
${ }^{1}$ Open Access Centre for Marine Research,

Waterborne Transport Technologies Laboratory,

Klaipeda University,

H. Manto 84, LT-92294 Klaipeda, Lithuania

${ }^{2}$ Open Access Centre for Marine Research,

Marine Chemistry Laboratory,

Klaipeda University,

H. Manto 84, LT-92294 Klaipeda, Lithuania

${ }^{3}$ Department of Marine Engineering,

Faculty of Marine Technologies and Natural Sciences,

Klaipeda University,

H. Manto 84, LT-92294 Klaipeda, Lithuania

${ }^{\text {*} C o r r e s p o n d i n g ~ a u t h o r, ~ e-m a i l: ~ w a t e r b o r n e . t r a n s p o r t @ a p c . k u . l t ~}$
}

\section{Introduction}

Transport sector is one of the biggest energy consumers in the market resulting in over $26.6 \%$ of total energy consumption globally and $33 \%$ in Europe and as a result one of the biggest air polluters with a continuing growth projected by the European commission (Eurostat; Industry news). A significant part of this comes from marine transport sector (Colvile et al., 2001). However, transport sectors are governed by different environmental requirements that gradually increase to levels where general fossil fuel such as diesel is no longer sufficient without a significant investment to exhaust gas cleaning. Greatest impact from marine transportation can be seen in $\mathrm{SO}_{\mathrm{x}}$ and $\mathrm{NO}_{\mathrm{x}}$ pollutant balance (EEB). According to EEB (European Environmental Bureau) data in $2015 \mathrm{SO}_{x}$ emission in the Baltic Sea was 10000 ton and $\mathrm{NO}_{\mathrm{x}}$ emission in the same territory was around 3420000 ton (BMEPC, 2016). After the implementation of stricter environmental regulations, these emissions are expected to decrease.

The decrease of nitrogen oxides below Tier II requirements is achievable in ships engines by implementing primary emission reduction technologies. This method also allows to come close to tier III requirements but not beyond it and in practice is not yet achievable in commercial ship engines (for example two stage air charge is effective but not yet commercially available) (Lappi et al., 2015). To assure the compliance with Tier III requirements it is necessary implement secondary emission cleaning technologies (Brynolf et al., 2014). Reduction of $\mathrm{SO}_{\mathrm{x}}$ can be achieved in two ways - use of low sulphur fuels or secondary exhaust gas cleaning technologies also known as scrubber. Secondary exhaust gas cleaning technologies are effective way of reducing harmful emissions but they require large investments, essential modernization of propulsion plant and superstructure furthermore installation means docking, loss of revenue and additional costs (Panasiuk, 2012; Panasiuk and Turkina, 2015; Österman, 2013).

In the EU commission scenario (EU Reference Scenario, 2016) it is projected that demand for heavy fuel oil increases at low rates (by $8 \%$ by 2020 ), being progressively substituted by marine diesel oil and liquefied natural gas (LNG). Notably, demand 
for LNG for use as a marine fuel is expected to reach 7.3 Mtoe by 2050 (i.e. $10 \%$ of the overall energy needs of international maritime bunkers) (EU Reference Scenario, 2016). The part of natural gas $(\mathrm{NG})$ in global energy market is expected to increase significantly, worldwide NG consumption is projected to increase from 3.4 trillion cubic meters $\left(\mathrm{Tm}^{3}\right)$ in 2012 to $5.75 \mathrm{Tm}^{3}$ in 2040 (expected to reach $23.6 \%$ - second largest position after coal in $2035)$ as it is the fastest growing primary energy source $(1.6 \%$ $1.8 \%$ per year) (Cedigaz, 2015; IEO, 2016).

\section{Factors restricting maritime transport pollution}

The current requirements of Marpol 73/78 Convention annex VI limit the emissions of sulphur and nitrogen oxides. In sulphur emission control zones, the sulphur content of marine fuels from 2015 is limited to $0.1 \%$ by mass (kilograms of sulphur per kilogram of fuel) and not in emission control zones up to $3.5 \%$ by weight now and up to $0.5 \%$ from 2020 . Limits of nitrogen oxides emissions are implemented at progressively tightening levels (Tier I, II, III) applicable according to the date of construction / modernization of a ship (Table 1). It is worth noting that Tier 3 limits in NECA (Nitrogen Emission Control Area) zones are up to $75 \%$ lower than Tier II (Lindstad and Eskeland, 2016; DNV GL, 2015).

Table 1 Marpol 73/78 Annex VI regulations for $\mathrm{NO}_{\mathrm{x}}$ emissions

\begin{tabular}{lcccc}
\hline \multirow{2}{*}{ Tier } & Date & \multicolumn{4}{c}{$\mathrm{NO}_{\mathrm{x}}$ limit, g/kWh } \\
\cline { 3 - 5 } & & $\mathrm{n}<130 \mathrm{~min}^{-1}$ & $130<\mathrm{n}<2000 \mathrm{~min}^{-1}$ & $\mathrm{n}>2000 \mathrm{~min}^{-1}$ \\
\hline I & 20000101 & 17.0 & $45 \cdot \mathrm{n}^{-0.2}$ & 9.80 \\
\hline II & 20110101 & 14.4 & $44 \cdot \mathrm{n}^{-0.23}$ & 7.70 \\
\hline III* & 20160101 & 3.4 & $9 \cdot \mathrm{n}^{-0.2}$ & 1.96 \\
\hline
\end{tabular}

* Only applicable to ships operating in NECA areas;

* Tier III requirements will take effect in the North American and US Caribbean Emission Control Areas (ECAs) from January 1st 2016 as per the latest MEPC 66 meeting (DNV GL, 2015; Chougle, 2017).

In order to reduce greenhouse gas emissions $\left(\mathrm{CO}_{2}\right)$ for new construction vessels, IMO has introduced the Energy Efficiency Design Index (EEDI) for ships between 3,000 and 15,000 DWT. This indicator is intended to encourage ship owners to seek energy efficiency.

The EEDI baseline determines how much $\mathrm{CO}_{2}(\mathrm{~g})$ can a vessel discharge per transport unit, it is based on the global average $\mathrm{CO}_{2}$ emissions of the ship type and also depends on the size of the vessel. For this indicator, the requirements for ships will be progressively tightened (\% indicating how much lower the ship's base value is) and, in the future, their fulfilment may raise engineering challenges or become unachievable by using conventional fuels (Ančić and Šestan, 2015; Bøckmann and Steen, 2016). The Energy Efficiency Operational Indicator (EEOI) was introduced to assess the efficiency of fleet performance. Unlike the EEDI, the EEOI indicator is not mandatory, it is described by the equation (Perera and Brage, 2016):

$$
\overline{E E O I}=\sum_{i=1}^{n_{V}} \sum_{j=1}^{n_{F}} F_{C i, j} C_{F_{j}} / \sum_{i=1}^{n_{V}} M_{c \arg o, i} D_{i}
$$

Here: $n_{V}$ the total number of voyage segments, $n_{F}-$ the total number of fuel types, $\mathrm{F}_{\mathrm{C}}$ - the mass of consumed fuel, $\mathrm{C}_{\mathrm{F}}-$ the fuel mass to $\mathrm{CO}_{2}$ mass conversion factor, $\mathrm{M}_{\text {cargo }}$ - the cargo carried (tonnes) or work done (number of TEU or passengers) or gross tonnes for passenger ships and D - the distance travelled by the vessel.

Ship Energy Efficiency Management Plan (SEEMP) is a mandatory indicator of ship energy efficiency. It builds on the vessel's EEOI index over a period of time and encourages ship owners to monitor ship energy efficiency indicators as well as implement measures to improve them (Perera and Brage, 2016). Summarizing these measures has one common goal - to reduce $\mathrm{CO}_{2}$ emissions from ships and other pollutants, but does not specify concrete methods how to achieve it, and this is also not reflected in the EEDI accounting reports (Rehmatulla et al., 2017).

In order to evaluate the effectiveness of implemented technologies EU developed the MRV (Regulation on the Monitoring Reporting and Verification of shipping emissions) regulation, according to this regulation after 2018 ships above 5000 GT that come to the EU or EFTA (European Free Trade Association) ports, will have to prepare $\mathrm{CO}_{2}$ emission reports. The reports will have to include $\mathrm{CO}_{2}$ emissions per trip. Reports will have to be validated by independent classification societies and submitted to the European Maritime Safety Organization (EMSA), which will publicize the synthesized material in 2019 (DNV GL). In addition to these control measures, there is also the objective of implementing market measures such as the Maritime emission trading scheme or Carbon tax, but their introduction has become very problematic due to the expected high economic impact of shipping companies and the choice of an efficient accounting system and currently is not reached (Lee et al., 2013; Sheng et al., 2017).

Table 2 Regulatory documents regulating air pollution from ships

\begin{tabular}{|c|c|c|c|}
\hline Requirement & $\begin{array}{c}\text { Limit / Accounting } \\
\text { Parameter }\end{array}$ & Evaluation Criterion & $\begin{array}{c}\text { Responsible } \\
\text { authority }\end{array}$ \\
\hline \multirow{2}{*}{$\begin{array}{l}\text { Marpol 73/78 } \\
\text { Annex VI }\end{array}$} & $\mathrm{NO}_{\mathrm{x}}$ emission & $\mathrm{g} / \mathrm{kWh}$ & \multirow{3}{*}{ IMO } \\
\hline & $\mathrm{SO}_{\mathrm{x}}$ emission & $\begin{array}{l}\text { Percentage of s } \\
\text { in fuel }(\%)\end{array}$ & \\
\hline EEDI & \multirow{3}{*}{$\mathrm{CO}_{2}$ emission } & \multirow{3}{*}{$\begin{array}{c}\mathrm{CO}_{2} / \text { transport } \\
\text { work unit }\end{array}$} & \\
\hline EEOI & & & - \\
\hline EU MRV & & & EMSA \\
\hline SEEMP & Energy efficiency & - & - \\
\hline
\end{tabular}

The increasing amount of ecological and energy efficiency requirements for marine engines and the rigor of standards make shipbuilders and engine manufacturers look for costeffective ways to meet standards. One of the most effective 
methods is to use NG fuelled engine (Burel et al., 2013; Attah and Bucknall, 2015; Yoo, 2017; Wik and Niemi, 2016). This is especially true for shipping, where the Marpol Convention's requirements for sulphur and nitrogen oxide emissions can be met by using modern NG fuelled engines.

\section{Natural gas as a fuel}

Usually gaseous fuels are divided into oil, industrial and natural gas. NG is extracted from gas deposits. NG contains methane most of all, and a small amount of other components and impurities. Oil gas is produced in the extraction of oil, it mainly consists of methane, ethane and propane. Industrial gas is formed during oil refining, mainly consists of propane and butane (Jučas, 1992). Gaseous fuels are multicomponent gas mixture, it is useful to present the physical properties of its main components (Table 3) (Karim, 2015; Barmin and Kunis, 2009).

Table 3 Properties of main hydrocarbon fuel gases

\begin{tabular}{|c|c|c|c|c|c|c|}
\hline Methane & Ethane & Propane & Propene & Butane & Iso-Butane & Butene \\
\hline \multicolumn{7}{|c|}{ Energy content (MJ/kg) } \\
\hline 50.01 & 47.48 & 46.35 & 45.78 & 45.74 & 45.59 & 45.32 \\
\hline \multicolumn{7}{|c|}{ Gas density $\left(\mathrm{kg} / \mathrm{m}^{3}\right)$} \\
\hline 0.717 & 1.357 & 2.019 & 1.915 & 2.703 & 2.668 & 2.503 \\
\hline \multicolumn{7}{|c|}{ Liquid density (kg/l) } \\
\hline 0.466 & 0.572 & 0.501 & 0.519 & 0.601 & 0.549 & 0.607 \\
\hline \multicolumn{7}{|c|}{ Liquid energy density (MJ/1) } \\
\hline 23.30 & 27.16 & 23.22 & 23.76 & 27.49 & 25.03 & 27.51 \\
\hline \multicolumn{7}{|c|}{ Gas energy density $\left(\mathrm{MJ} / \mathrm{m}^{3}\right)$} \\
\hline 32.6 & 58.4 & 84.4 & 79.4 & 111.4 & 110.4 & 113.0 \\
\hline \multicolumn{7}{|c|}{ Gas specific gravity $\left(25^{\circ} \mathrm{C}\right)$} \\
\hline 0.55 & 1.05 & 1.55 & 1.47 & 2.07 & 2.06 & 1.93 \\
\hline \multicolumn{7}{|c|}{ Boiling point $\left({ }^{\circ} \mathrm{C}\right)$} \\
\hline-164 & -89 & -42 & -47 & -0.5 & -12 & -6.3 \\
\hline \multicolumn{7}{|c|}{ Heat of evaporation $(\mathrm{kJ} / \mathrm{kg})$} \\
\hline 509 & 490 & 427 & 438 & 386 & 381 & 359 \\
\hline
\end{tabular}

According to the state, the gas is divided into liquefied petroleum gas (LPG), compressed $\mathrm{NG}$ and LNG. Natural gas fuel is well-known as fuel for vessel power plants. The experience of using LNG began in 1964, when the LNG carrier started using the boil off gas as fuel (Einang and Haavik, 2000). By "LNG world shipping" in March of 2017 in service was 103 LNG powered vessels that are not LNG carriers (Corkhill, 2017). Compressed natural gas (CNG) using on ships is not so popular, there are only a few vessels operating on CNG (StuesLauridsen et al., 2010) and mainly considered as fuel for inland waters (Dorokhov et al., 2012).

Rapid progress has been made worldwide in recent years in the discovery of new NG deposits. Its increased availability, the need to meet increasingly lower engine exhaust emission controls, and its relatively low cost have tended to increase its usage as a fuel in a wide variety of applications. The gas has been increasingly viewed as a premium fuel that is in much demand, and may well be for quite some time in the future a prime source of usable fuel energy. The composition of raw NG varies significantly, depending on its source and whether it has been processed for pipeline distribution and consumption or not. Typically, NG as delivered to consumers is suitably processed and composed of about $90 \%$ methane, and the remainder is of various concentrations of ethane, propane, butane, and non-fuel-diluent gases, such as nitrogen and carbon dioxide (Jučas, 1992; Karim, 2015).

CNG is produced by compressing the conventional NG to less than $1 \%$ of the volume it occupies at standard ambient pressure. $\mathrm{CNG}$ technology requires the use of a high-pressure tank and a different refilling system. Ships using CNG require a highpressure fuel tanks and high-pressure fuel supply system. NG has to be compressed to $\sim 20 \mathrm{MPa}$, which increases its density to $\sim 140$ $\mathrm{g} / \mathrm{l}$, it typically correspond on an energy basis to an equivalent amount of gasoline of merely around $30 \%$ by volume. The weight, bulk, and cost of the fuel tanks remain a serious limitation to the wide application of $\mathrm{CNG}$, particularly for transport. They can constitute a high cost of the conversion to fuel gas operation (Jučas, 1992; Karim, 2015; Khan et al., 2015).

For efficient transportation, $\mathrm{NG}$ is liquefied in special liquidation plants that are usually near the gas source. Liquefied gas is then transported and distributed large distances via specialized LNG tankers (Karim, 2015). The liquidation process effects the composition of NG. Ethane, propane, butanes and heavier hydrocarbons, carbon dioxide and hydrogen sulfides are removed and the gas dried. After the process, remaining $\mathrm{NG}$ can have up to $3-4 \%$ ethane, $2-3 \%$ propane, $2 \%$ butane and $1.5 \%$ of nitrogen. The density of LNG compared to NG is 600 times greater; this reduces the size of storage and transportation tanks. LNG is colorless, odorless liquid with half the density of water. LNG floats on the surface of water without mixing (Fiodorova, 2011). The use of LNG in transport engines is attractive because of higher energy density in comparison to $\mathrm{CNG}$. Using $\mathrm{LNG}$ instead of $\mathrm{CNG}$ means lighter fuel system, faster refueling, uniform fuel quality and lower refueling facility costs. Due to liquid state of LNG it can be pressurized to high levels with cryogenic pumps (Karim, 2015). Use of $\mathrm{NG}$ in internal combustion engines produces a lot less $\mathrm{CO}_{2}, \mathrm{NO}_{\mathrm{x}}, \mathrm{SO}_{\mathrm{x}}$ and $\mathrm{PM}$ at the same amount of energy, because of lower carbon content in comparison to other fuels [38]. Exhaust gases also contain no solid particles and sulphur oxides. Gas fuels combust more efficiently, than oil fuels or coal, but the emissions depends on not only the fuel type but also on how it is combusted (Fiodorova, 2011). According to different studies, the emissions from ships with dual fuel engines showed significantly lower $\mathrm{NO}_{x}$ and $\mathrm{CO}_{2}$ emissions in comparison to the gas oil. $\mathrm{NO}_{\mathrm{x}}$ emissions can be reduced up to 
$90 \%$ and $\mathrm{CO}_{2}$ up to $20 \%$ but hydrocarbon and carbon monoxide emissions were higher Anderson et al., 2015; Thomson et al., 2015; IMO, 2016; GB Transport Committee, 2012).

NG contains virtually no sulphur and therefore the engine can operate without restriction in SECA areas, but after the entry into force of Marpol Annex VI third level requirements for nitrogen oxide emissions, in NECA zones, the use of gas alone is not always sufficient (GB Transport Committee, 2012; Lloyd's register):

- gas engines operating in the Otto or Miler cycle can achieve compliance with Marpol Tier III requirements;

- dual-fuel engines are certified at the Tier II level (when using liquid fuel) and Marpol Tier III (in case of fuel gas injection) using a special test procedure. The dual-fuel engine can also be certified as a gas engine, but then liquid fuel can only be used in emergencies.

\section{Supply of non-road piston IC engines able operate on natural gas}

Natural gas use in marine engine in many cases ensures that vessel allowed to operate in the emission control zones (ECA) without any additional exhaust gas aftertreatment systems. Marine engine producers "MAN Diesel \& Turbo SE", "Wärtsilä", "Caterpillar Inc.", "Hyundai Heavy Industries", "Kawasaki Heavy Industries", "Rolls-Royce” (Wärtsilä, 2015; MAN Diesel \& Turbo; Wartsila Engines \& Generating; CAT; Hyundai; Kawasaki; Rolls-Royce) state that their marine gas engines ensure Marpol 73/78 Tier III requirements. Other advantage of NG use is related to dual-fuel (diesel/heavy fuel oil-NG) engines operation when ship owners able to optimise their costs due to price difference between liquid and gaseous fuels.

The principle of NG use in marine engines is close to liquid fuel one. One of the ways is more primitive - when NG realized in Otto cycle (spark ignition engines) and NG is the only one fuel. Such engines generate power in the range of $\sim 25-11000$ $\mathrm{kW}$. This type engines are rarely classified as marine engines because in many cases they could be customized (usually they are purposed) for other sectors (stationary energy, mining, special purpose transport, oil industry, etc.). "Kawasaki Heavy Industries" (Kawasaki), "Rolls-Royce" (Rolls-Royce) and "General Electric" (General electric) spark ignition engines are presented as marine engines due to their mass an power, however, if necessary, they can work in stationary power units. Market of various purpose gas engines is rich in participants: "MAN Diesel \& Turbo SE", "Dresser-rand", "MWM", "MTU", "Weichai", "Perkins", "Cummins", "Deutz", “Caterpillar Inc.”, etc.

\subsection{Spark ignition gas engines}

In spark ignition (SI) piston engines $\mathrm{NG}$, as a fuel, used via usual Otto cycle when the in-cylinder charge ignites from an additional source (spark plug). Usually NG is injected into intake air flow (intake manifold) and ignited in cylinder by spark plug. Comparing to dual-fuel technology, the use of NG in SI engines is more primitive, however a part of engine producers improve the design - use pre-chambers with spark plug ("MAN Diesel \& Turbo SE", "Wärtsilä” and etc.), others investing in ignition control, improving the Miller cycle (MTU, etc.), and etc. The main part of SI engines are purposed and used in land - electricity production, special purpose transport, oil extraction engineering units, etc. These engines are not widespread in shipping sector due to objective reasons - to avoid restrictions related to wide operation areas (lack of port infrastructure for NG bunkering), and for that reason main part of ships are designed to use liquid fuels: Marine Gas Oil (MGO), Marine Diesel Oil (MDO), Heavy Fuel Oil (HFO). The latter are available in practically all over the world, and the gaseous fuel supply infrastructure is less developed than liquid fuel. However the gas engine use in ship power plants becomes more relevant due to stricter pollution control requirements in Emission Control Areas (ECAs) and in the same time bunkering problems are solving and new projects are being implemented.

The analysis of marine SI engines is difficult due to the mentioned reason - in many cases, engines are multipurpose and manufacturers do not detail their purpose or field of application. However high power "Bergen" ("Rolls-Royce") engines (RollsRoyce), that purposed for ship propulsion and work with electric generator, must be mentioned: C26:33L (engine modifications C26:33L6PG, C26:33L8PG, C26:33L9PG 1460-2430 kW, at $\left.900 / 1000 \mathrm{~min}^{-1}\right)$, B35:40L9PG $\left(3940 \mathrm{~kW}\right.$, at $\left.750 \mathrm{~min}^{-1}\right)$, B35:40V12PG (5700 kW, at $\left.750 \mathrm{~min}^{-1}\right)$. As well "Kawasaki Heavy Industries" supplies four stroke marine engine series L30KG (6, 8 and 9 cylinders, $2670-4005 \mathrm{~kW}$, at $\left.750 \mathrm{~min}^{-1}\right)$ that can be used as propulsion engines or in gen-set units (Kawasaki). "General Electric" piston gas engine series "JENBACHER TYPE 2/3/4/6" (General electric) which includes engines:

- J208 (299 and $335 \mathrm{ekW}, 50 / 60 \mathrm{~Hz}$ );

- J312 (405 and $633 \mathrm{ekW}, 50 / 60 \mathrm{~Hz}$ ), J316 (835 and 848 ekW, 50/60 Hz), J320 (1067 and 1059 ekW, 50/60 Hz);

- J412 (850 ekW, 50/60 Hz), J416 (1137 ekW, 50/60 Hz), J420 (1426 ekW, 50/60 Hz);

- J612 (2004 and 1979 ekW, 50/60 Hz), J616 (2679 and $2649 \mathrm{ekW}, 50 / 60 \mathrm{~Hz}$ ), J620 (3360 and $3325 \mathrm{ekW}, 50 / 60$ Hz), J624 (4401 ekW, 50/60 Hz);

- J920 Flextra (10400 and 9350 ekW, 50/60 Hz).

As well company "General Electric" supplies engine series "WAUKESHA" for transport means and stationary energy units (General electric):

- VGF48GSID, VGF48GL/GLD, VGF48GL (LCR) - 50 Hz: 625/685/625 ekW, 60 Hz: 750/830/750 ekW;

- VGF36GSID,VGF36GL/GLD,VGF36GL (LCR) - 50 Hz: 475/515/475 ekW, 60 Hz: 560/620/560 ekW;

- VGF24GSID, VGF24GL/GLD, VGF24GL (LCR) 50/60 Hz: 375/415/375 ekW; 
- VGF18GSID, VGF18GL/GLD, VGF18L (LCR) - 50 Hz: 230/255/234 ekW, 60 Hz: 230/307/279 ekW;

- VHP9504GSI emPact, VHP7104GSI emPact, VHP7100GSI S4 emPact,VHP7100GL 50 Hz: 1460/1100/875/875 ekW, 60 Hz: 1600/1200/1050/1050 ekW;

- MobiFlex VHP7104GSI, VHP L7044GSI, VHP5904GSI,VHPL5794GSI(50Hz: 1153/1153/947/947 kW, 60 Hz: 1253/1253/1029/1029 kW);

- 16V275GL+, 12V275GL+ (50 Hz: 3605/2705 ekW, 60 Hz: $3215 / 2415 \mathrm{~kW})$.

Multipurpose low power (37-580 kW) four stroke SI gas engines (E0834, E0836, E2676, E2876, E2848, E3268, E2842, E3262) are supplied into market by company "MAN Diesel \& Turbo SE" (MAN Diesel \& Turbo). As well this company supplies high power SI gas gen-sets that have power: with 51/60G and 51/60G TS (two-stage turbocharged) series engines 18654-20431 $\mathrm{ekW}$ (500 and $514 \mathrm{~min}^{-1}$ ), 35/44G and 35/44G TS (two-stage turbocharged) 10420-10027 ekW and 6945-12214 ekW (at 720 and $750 \mathrm{~min}^{-1}$ ) respectively.

Company “Wärtsilä" offers the most powerful 4 stroke SI gas engine 18V50SG $\left(18810 \mathrm{~kW} / 18321 \mathrm{ekW}\right.$ at $50 \mathrm{~Hz} / 500 \mathrm{~min}^{-1}$ and $19260 \mathrm{~kW} / 18759 \mathrm{ekW}$ at $60 \mathrm{~Hz} / 514 \mathrm{~min}^{-1}$ ) and slightly less powerful gas gen-sets 9/16/20 L34SG and 20 L34SG with turbo generator, whose power varies in range of $4380-9520 \mathrm{ekW}$ (50/60 Hz at 750/720 $\mathrm{min}^{-1}$ respectively) (Wartsila Engines).

Company "Caterpillar Inc." has one of the largest supply capacities of SI gas engines. The large part of these engines are purposed to work in gen-set units, other part purposed for vehicle propulsion systems. "Caterpillar Inc." engines able to use NG, biogas, propane, coal gas, well gas (detailed information presented in manufacturer documentation). Also the supply of "Caterpillar Inc." engines gives possibility to be flexible choosing engine according ranges of size, power, revolutions and etc. The company produces multipurpose (for industry, small energy, cogeneration, landfill gas recovery, mining, oil and gas extraction industry, special purpose vehicles, etc.) SI four stroke engines that able to work on different kind of gas (CAT), however these engines are rarely used in ships due to specifics of gaseous fuels use in waterborne transport:

- for electricity generation:

- low power engines (DG30-2, DG50-2, DG60-2, DG80-2, DG100-2, DG125-2, G3306, DG150-2, G3406), electric power range is $30-235$ ekW (at $\left.1500 / 1800 \mathrm{~min}^{-1}\right)$;

- average power (400-1041 ekW at 1200/1500/1800 $\mathrm{min}^{-1}$ ) engines (CG132-8, G3412, G3508A, CG13212, G3512A, CG132-16, G3512E, G3516A);

- high power engines (CG170-12, G3516B, CG17016, G3516E, G3516C, CG170-20, G3516H, G3520E, G3520C, CG260-12, CG260-16) in gen-set units generate electric power $1200-4500 \mathrm{ekW}$ (at 900/1000/1200/1500/1800 $\mathrm{min}^{-1}$ );

- for direct power transmission:

- low power engines (G3304, G3306, G3406, G3408) that power varies in range of $71-317 \mathrm{~kW}$ at 1500 or $1800 \mathrm{~min}^{-1}$;

- average power engines (G3412, G3508/G3508B, G3512/G3512B, G3516/G3516B), their power range is $475-1030 \mathrm{~kW}$ at $1200 / 1400 / 1800 \mathrm{~min}^{-1}$;

- high power engines (G3520/G3520B) that maximal power reach $1285 \mathrm{~kW}$;

- gas compression engines for oil and gas industry:

- low power engines (G3304B, G3306B, G3406, G3408, G3408C, CG137-8) that power varies in range of $71-317 \mathrm{~kW}$ at $1200 / 1400 / 1800 \mathrm{~min}^{-1}$;

- average power engines (G3412, CG137-12, G3508, G308B, G3512, G3512B, G3516, G3516B, G3516J) their power range is $447-1030 \mathrm{~kW}$ at $1400 / 1800 \mathrm{~min}^{-1}$;

- high power engines (G3520B, G3606, G3608, G3612, G3616, G3606 A4, G3608 A4, G3612 A4, G3616 A4, G12CM34, G16CM34) that power range is 1100 $6100 \mathrm{~kW}$ at $450 / 1000 \mathrm{~min}^{-1}$

SI gas engines "CAT" have wide application possibilities and due to this a part of mentioned engine models are repeated in different purpose engine groups. Engine power groups (low/ average/high power) were chosen after "Caterpillar Inc." SI gas engine supply analysis: low power - up to $400 \mathrm{~kW}( \pm 10 \%)$; average - 400-1000 kW ( $\pm 10 \%)$; high power - from $1000 \mathrm{~kW}$ $( \pm 10 \%)$.

SI gas engines are not popular in merchant shipping for obvious reasons - less operation time till maintenance, lower relative power ( $\mathrm{kW} /$ cylinder), lower torque, specificity of gaseous fuel bunkering, fuel selection inflexibility and etc.

\subsection{Marine dual-fuel engines}

The supply market of dual-fuel (diesel-NG) marine engines is dominated by the several large companies that have many years of experience in diesel engines production field. This market is dominated by companies such as "MAN Diesel \& Turbo SE", "Wärtsilä", "Caterpillar Inc." and "Hyundai Heavy Industries". Also a part of mentioned companies supplies SI gas engines. Other companies ("Cummins", "Yanmar" and "Weichai") have a small supply in the low power engine segment, which are purposed to ensure energy or power needs in mining, oil industry, etc.

Company's "MAN Diesel \& Turbo SE" attention, apart from usual IC engine manufacture, focused on dual-fuel engine manufacture. This company supplies various power and speed engines into market, they ensure Marpol 73/78 Annex VI Tier III (further Tier III) when operate in dual-fuel mode: four stroke propulsion and auxiliary engines L35/44DF (3060-5300 kW), 
L51/60DF (6-9 cylinders, 5850-9000 kW), V51/60DF (12, 14, 16, 18 cylinders, $11700-23800 \mathrm{~kW}$ ) and L28/32SDF (5-9 cylinders, $1000-1800 \mathrm{~kW}$ ) with low pressure gas injection in to intake manifold technology. Also market is supplied by two stroke high power series ME modified engines which can partially replace oil products consumption: low speed engine series ME-GI with high pressure direct gas injection S70-ME-C8-GI (16350-26160 $\mathrm{kW})$, S65-ME-C8-GI (14350-22960 kW) and S60-ME-C8-GI (11900-19040 kW); ME-LGI series with volatile liquids or liquid gas (methanol, ethanol, dimethyl ether and liquefied petroleum gas) direct injection in cylinder; ME-LGIM engines which use a main part of methanol and pilot portion is oil fuel (HFO, MDO or MGO). The distribution of power ranges is presented in Fig. 1.

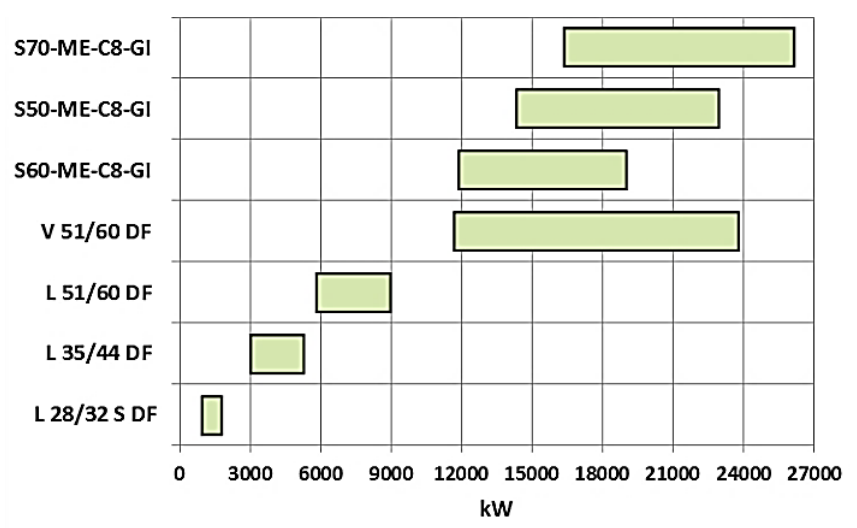

Fig. 1 The distribution of "MAN Diesel \& Turbo SE" dual-fuel engines power range

The supply of "CAT" SI gas engines is much bigger than supply of dual-fuel engines purposed for merchant shipping and stationary energy units. "CAT" engines that able to use gas in dual-fuel cycle (MDO/HFO-NG) could be divided into two groups - propulsion engines and gen-set purpose (Fig. 2):

- propulsion engines manufactured under "MaK" brand and three different power engine models are supplied into market: M 34 DF (6, 8 or 9 cylinders, $3060-4770 \mathrm{~kW}$, at 720/750 $\mathrm{min}^{-1}$ ), M 46 DF (6-9 cylinders, 5400-8685 $\mathrm{kW}$, at 500/514 $\mathrm{min}^{-1}$ ) and VM $46 \mathrm{DF}(12$ and 16 "V" form, $10800-15440 \mathrm{~kW}$, at 500/514 $\mathrm{min}^{-1}$ ). Same engines are used as gen-set IC engines, such gen-sets generates electric power in a range of 2934-14807 ekW;

- powerful IC engines (6CM34DF, 8CM34DF, 6CM46DF, 7CM46DF, 8CM46DF, 12CM46DF, 16CM46DF) together with electric generators generate 2880-14976 ekW at $720 \mathrm{~min}^{-1}(60 \mathrm{~Hz})$ and $750 \mathrm{~min}^{-1}(50 \mathrm{~Hz})$.

"Wärtsilä" company is another strong and well-known manufacturer of marine gas engines (Wartsila Engines). This company, apart usual diesel engine production, manufactures dual-fuel engines with high pressure gas injection into cylinder technology. These engines (Fig. 3) ensure Marpol Tier III requirements in dual-fuel mode:
- four stroke engine for gen-set units, series 20DF (6, 8,9 cylinders $1110-1665 \mathrm{~kW}$ at $1200 \mathrm{~min}^{-1}$ ) with low pressure gas injection system. These engines are able to run on HFO-gas, distillates-gas and HFO-distillates fuel modes generating $185 \mathrm{~kW}$ of power per cylinder. Also the manufacturer claims that this series engines able to run on biofuels;

- four stroke engine series 31DF ("V" form 8, 10, 12, 14 and 16 cylinders, $4200-8800 \mathrm{~kW}$ at 720 and $750 \mathrm{~min}^{-1}$ ) for propulsion (could be used in gen-set units) that is made on "Wärtsilä" 31 engine series base. This series have 3 modifications that able to run on different fuel modes: diesel fuel, dual-fuel and pure gas. 31 diesel engine series is included in the Guinness Book of World Records as the most effective 4 stroke diesel engine series;

- four stroke engine series 34DF for propulsion, however it can be used as gen-set IC engine. This series engines have 6,8 or 9 in-line cylinders that generates power in the range of $3000-4500 \mathrm{~kW} .12$ and 16 cylinders "V" form engines generate 6000 and $8000 \mathrm{~kW}$ at $750 \mathrm{~min}^{-1}$;

- four stroke engine series 46DF for propulsion (could be used in gen-set units) which has a very good power-mass ratio. The power per cylinder reaches $1045 \mathrm{~kW}$ or 1145 $\mathrm{kW}$ at $600 \mathrm{~min}^{-1}$. Engine series equipped by low pressure gas injection technology;

- high power four stroke engine series 50DF that consists of 6,8 and 9 in-line cylinders engines (6/8/9L50DF, $5700-8550 \mathrm{~kW}$ ) and "V" form 12, 16 and 18 cylinders engines (12/16/18V50DF, 11400-17550 kW). Engines are flexible for different fuel use - with low pressure gas injection system could operate in chosen fuel modes: HFO-gas, distillates-gas and HFO-distillates. They generate 950 or $975 \mathrm{~kW} /$ cylinder at $\left(500 / 514 \mathrm{~min}^{-1}\right)$ and usually these engines are used in gen-set units.

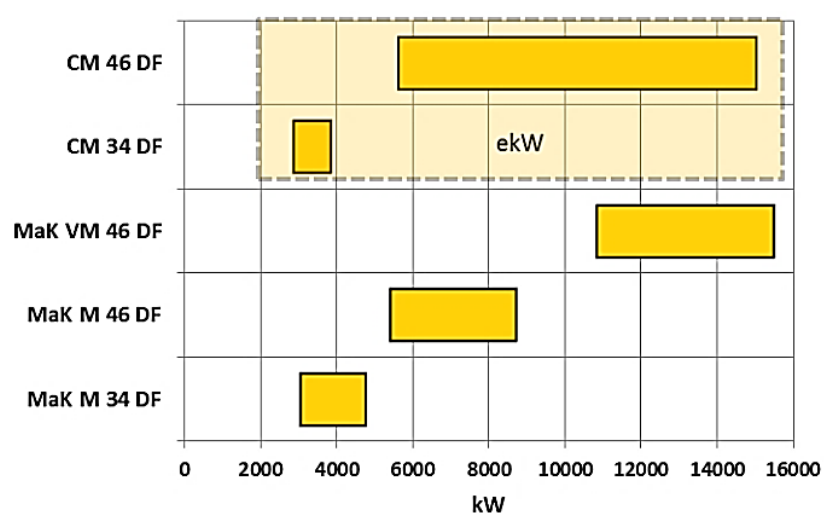

Fig. 2 The distribution of "Caterpillar Inc." and "MaK" dual-fuel engines power range

The company "Wärtsilä" is in close cooperation with the Swiss company "Winterthur gas and diesel" ("WinGD"), together they supply high power two stroke low speed dual-fuel 
engines (RT-flex50DF, W-X52DF, W-X62DF, W-X72DF, $\mathrm{W}-\mathrm{X} 82 \mathrm{DF}, \mathrm{W}-\mathrm{X} 92 \mathrm{DF}$ ) for propulsion (Wingd). The rated speed on these engines varies in range of 65-124 $\mathrm{min}^{-1}$, power - 7450-63840 kW (Fig. 4), bore - 500-920 mm and stroke 2050-3468 mm.

"HiMSEN" is dual-fuel engine series from company "Hyundai Heavy Industries" (Hyundai). The series consists of 6-9 in-line cylinders engines H35DF (2880-4320 kW at $720 / 750 \mathrm{~min}^{-1}$ ) and 12, 14, 16, 18 and 20 "V" form cylinders engines H35DFV (5760-9600 kW at 720/750 $\mathrm{min}^{-1}$ ). Engines HiMSEN H35DF and H35DFV used in gen-set units, and ensure Marpol Tier II requirements when running on diesel fuel and Marpol Tier III in dual-fuel mode.

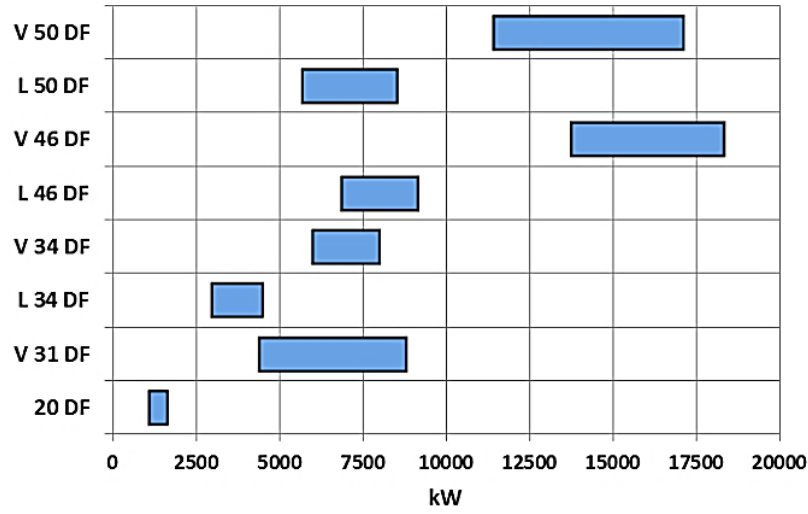

Fig. 3 The distribution of "Wärtsilä" dual-fuel engines power range

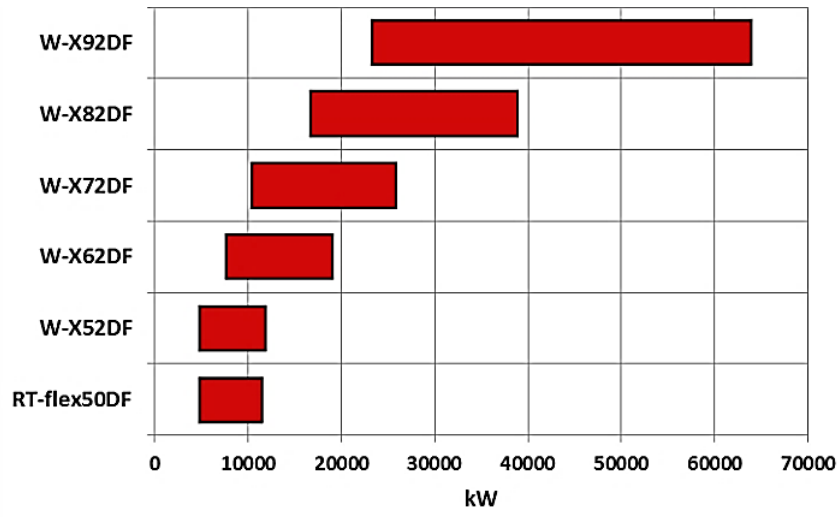

Fig. 4 The distribution of "Winterthur gas and diesel" dual-fuel engines power range

Also the single cases of well-known companies manufactured dual-fuel engines supply could be found in market. Company "Cummins" supplies the 4 stroke dual-fuel engine series Dual Fuel QSK50 (1044-1193 kW) with low pressure gas injection system, they purposed to ensure the energy needs of oil wells on land (Cummins), also can be used as a propulsion engine on small ships and in gen-set unit. Company "Yanmar" supplies marine engine 6EY26DF (Yanmar), which rated power is $1533 \mathrm{~kW}$ (at $750 \mathrm{~min}^{-1}$ ). Chinese company "Weichai Heavy Machinery" represents (Weichai) their dual-fuel products $6170(410 \mathrm{~kW})$ and $12 \mathrm{M} 26\left(500\right.$ and $700 \mathrm{~kW}$ at $\left.1900 \mathrm{~min}^{-1}\right)$.
Analysis shows that the main part of supplied dual-fuel engines is engines above $\sim 1000 \mathrm{~kW}$ and the supply of such power engines is week. So this case shows that mainly all market focused on ocean (sea) going ships, and small tonnage inland ships almost have no supply of dual-fuel engines up to $\sim 1000 \mathrm{~kW}$.

\section{Conclusion}

As pollution prevention becomes more and more important, pollution control tools are getting stricter. The allowed limits for SOx and NOx emission becomes lower in ECAs which are regulated by IMO Marpol Annex VI. Also the tools came into force or are planned to be involved into pollution control: Energy Efficiency Operational Indicator (EEOI), Ship Energy Efficiency Management Plan (SEEMP), Regulation on the Monitoring Reporting and Verification of shipping emissions (MRV), Maritime emission trading scheme (planned) and Carbon tax (planned).

The process of NG utilization in power plant is well-known for a long time and used wide in stationary energy sector as an alternative for liquid fuels. However NG powered ships are not common in shipping due to obvious reasons: competitive liquid fuel price, bunkering infrastructure specifics, the ensure cryogenic conditions during transport as a cargo and as a fuel (in the case of LNG) and etc.

Natural gas use in ship power plants makes lower rates of sulphur, nitrogen, carbon and other compounds concentration in exhaust gas. Strengthening environmental requirements lead the higher level of NG use especially in pollution in sensitive regions (Emission Controlled Areas).

In general view, the largest non-road purpose engine manufacturers "MAN Diesel \& Turbo SE", "Wärtsilä", "Caterpillar Inc.", "Hyundai Heavy Industries", "Kawasaki Heavy Industries", "Rolls-Royce" and etc., are ready to ensure the demand of gas using engine market. Comparing to spark ignition engines, dual-fuel engines are more preferable in shipping sector due to fuel use flexibility - to maneuver between the market fuel prices and the ensure of environmental requirements. However the supply of spark ignition gas engines is much bigger than dual-fuel due, this fact determined by the stationary energy sector with its demand of gas utilization units.

\section{References}

Anderson, M., Salo, K., Fridell, E. (2015). Particle - and Gaseous Emissions from an LNG Powered Ship. Environmental Science \& Technology. 49(20), pp. 12568-12575. https://doi.org/10.1021/acs.est.5b02678

Ančić, I., Šestan, A. (2015). Influence of the required EEDI reduction factor on the CO2 emission from bulk carriers. Energy Policy. 84, pp. 107-116. https://doi.org/10.1016/j.enpol.2015.04.031

Attah, E. E., Bucknall, R. (2015). An analysis of the energy efficiency of LNG ships powering options using the EEDI. Ocean Engineering. 110(Part B), pp. 62-74. https://doi.org/10.1016/j.oceaneng.2015.09.040 
Baltic Marine Environment Protection Commission (BMEPC) (2016). Marine working Group.Talin, Estonia. [Online]. Available from: https:/goo.gl/ sCLWCG [Accessed: 11th October 2017]

Barmin, I. V., Kunis, I. D. (2009). Сжиженный природный газ вчера, сегодня, завтра. Издательство: МГТУ им. Баумана. (Liquefied natural gas yesterday, today, tomorrow.) MGTU Bauman. (in Russian)

Bøckmann, E., Steen, S. (2016). Calculation of EEDI weather for a general cargo vessel. Ocean Engineering. 122, pp. 68-73. https://doi.org/10.1016/j.oceaneng.2016.06.007

Brynolf, S., Magnusson, M., Fridell, E., Andersson, K. (2014). Compliance possibilities for the future ECA regulations through the use of abatement technologies or change of fuels. Transportation Research, Part D: Transport and Environment. 28, pp. 6-18. https://doi.org/10.1016/j.trd.2013.12.001

Burel F., Taccani R., Zuliani N. (2013). Improving sustainability of maritime transport through utilization of Liquefied Natural Gas (LNG) for propulsion. Energy. 57, pp. 412-420. https://doi.org/10.1016/j.energy.2013.05.002

Cedigaz (2015). Medium and Long Term Natural Gas Outlook. [Online]. Available from: www.cedigaz.org/documents/2015/CEDIGAZProspects2015. pdf [Accessed: 12th October 2017]

Chougle, T. (2017). Marine Insight 7 Ways For Ships To Meet MARPOL NOx Tier III Regulation. [Online]. Available from: https://goo.gl/4oETmn [Accessed: 15th October 2017]

Colvile, R. N., Hutchinson, E. J., Mindell, J. S., Warrenam, R. F., Colvilea, R. N. (2001).The transport sector as a source of air pollution. Atmospheric Environment. 35(9), pp. 1537-1565. https://doi.org/10.1016/S1352-2310(00)00551-3

Corkhill, M. (2017). LNG-fuelled fleet hits 200 ship mark. LNG world shipping. [Online]. Available from: http://www.lngworldshipping.com/news/ view,Ingfuelled-fleet-hits-200-ship-mark_46977.htm [Accessed: 15th October 2017]

Cummins Dual Fuel Engines for Drilling. [Online]. Available from: https:// cumminsengines.com/dual-fuel [Accessed: 20th October 2017]

DNV GL. (2015). IMO NOx Tier III requirements to take effect on January 1st 2016. [Online]. Available from: https://goo.gl/ZKAoTw [Accessed: 1st November 2017]

DNV GL EU MRV Regulation. [Online]. Available from: https://www.dnvgl. com/maritime/eu-mrv-regulation/index.html [Accessed: 1st November 2017]

Dorokhov A. F., Apkarov I. A., Luong, H. Q. (2012). Особенностиприменения газообразных топлив в судовых энергетических установках. (Characteristics of the uze of the gaseous fuel in marine power plants.) Морскаятехника и технология. Marine engineering and technology. 2, pp. 70-75. (in Russian). [Online]. Available from: https://cyberleninka.ru/article/v/osobennosti-primeneniya-gazoobraznyh-topliv-v-sudovyh-energeticheskih-ustanovkah [Accessed: 1st November 2017]

Einang, P. M., Haavik, K. M. (2000). The Norwegian LNG ferry. Paper A-095, NGV, Yokohama

EU Reference Scenario. (2016). Energy, transport and GHG emissions Trends to 2050 European commission. [Online]. Available from: https://ec.europa.eu/energy/sites/ener/files/documents/ref2016_report_final-web.pdf [Accessed: 1st November 2017]

European Environmental Bureau (EEB). [Online]. Available from: http://eeb. org/ [Accessed: 1st November 2017]

Eurostat Statistics Explained. Final energy consumption, EU-28, 2015 (\% of total, based on tonnes of oil equivalent). [Online]. Available from: http:// ec.europa.eu/eurostat/statistics-explained/index.php/File:Final_energy_ consumption,_EU-28,_2015_(\%25_of_total,_based_on_tonnes_of_oil_ equivalent)_YB17.png [Accessed: 1st November 2017]
Fiodorova, Е. В. (2011). Современное состояние $u$ развитие мировой индустрии сжиженного природного газа: технологии $u$ оборудование. М.: РГУ нефти и газаим. Губкина. (The current state and development of the global liquefied natural gas industry: technologies and equipment.) Moscow, Gubkin Russian State University of Oil and Gas.) pp. 159. (in Russian)

General electric gas engines. [Online]. Available from: https://www.gepower. com/gas/reciprocating-engines [Accessed: 1st November 2017]

Great Britain: Parliament: House of Commons: Transport Committee (2012). Sulphur emissions by ships: sixteenth report of session 2010-12, 1, Report, together with formal minutes, oral and written evidence. pp. 78.

IMO (2016). Studies on the feasibility and use of LNG as s fuel for shipping. Air pollution and energy efficiency study series. 3. pp. 285. (pp. 81.) Industry news. The Damage Done in Transportation -- Which Energy Source Will Lead to the Greenest Highways?. [Online]. Available from: https://news.thomasnet.com/imt/2012/04/30/the-damage-done-in-transportation-which-energy-source-will-lead-to-the-greenest-highways [Accessed: 2nd November 2017]

International Energy Outlook (IEO). DOE/EIA-0484. (2016). [Online]. Available from: https://www.eia.gov/outlooks/ieo/pdf/0484(2016).pdf [Accessed: 2nd November 2017]

Li, J., Wu, B., Mao, G. (2015). Research on the performance and emission characteristics of the LNG-diesel marine engine. Journal of Natural Gas Science and Engineering. 27(2), pp. 945-954. https://doi.org/10.1016/j.jngse.2015.09.036

Jučas, P. (1992). Degalai ir tepalai: chemotologija. (Fuel and lubricants: chemotology.) Vilnius, Mokslas. (in Lithuanian)

Karim, G. A. (2015). Dual-fuel Diesel Engines. CRC Press, Taylor and Francis Group.

Khan, M. I., Yasmin, T., Shakoor, A. (2015). Technical overview of compressed natural gas $(\mathrm{CNG})$ as a transportation fuel. Renewable and Sustainable Energy Reviews. 51, pp. 785-797. https://doi.org/10.1016/j.rser.2015.06.053

Lappi, M., Borkowski, T., Myskow, J. (2015). Emissions reductions measures in maritime shipping. Naukowe Akademii Marskiej w Szczecin.

Lee, T. C., Chang, Y. T., Lee, P. T.W. (2013). Economy-wide impact analysis of a carbon tax on international container shipping. Transportation Research, Part A: Policy and Practice. 58, pp. 87-102. https://doi.org/10.1016/j.tra.2013.10.002

Lindstad, H. E., Eskeland, G. S. (2016). Environmental regulations in shipping: Policies leaning towards globalization of scrubbers deserve scrutiny. Transportation Research, Part D: Transport and Environment. 47, pp. 67-76. https://doi.org/10.1016/j.trd.2016.05.004

Lloyd's Register Marine. (2015). Your options for emissions compliance. Guidance for ship owners and operators on the Annex VI SOx and NOx regulations 2015. [Online]. Available from: https://issuu.com/lr_marine/ docs/213-35826_your_options_for_emission [Accessed: 3rd November 2017]

MAN Diesel \& Turbo SE products. [Online]. Available from: http://powerplants.man.eu/products [Accessed: 3rd November 2017]

Österman, C., Magnusson, M. (2013). A systemic review of shipboard SCR installations in practice. WMU Journal of Maritime Affairs. 12(1), pp. 63-85. https://doi.org/10.1007/s13437-012-0034-1

Panasiuk, I. (2012). Laivo išmetamųjų dujų toksiškumo mažinimo problematika. (Problems of reducing the toxicity of the ship's exhaust gases.) $M O K$ SLAS - LIETUVOS ATEITIS. (SCIENCE - FUTURE OF LITHUANIA.) 4(4), pp. 366-369. (in Lithuanian)

Panasiuk, I., Turkina L. (2015). The evaluation of investments efficiency of SOx scrubber installation. Transportation Research, Part D: Transport and Environment. 40, pp. 87-96. https://doi.org/10.1016/j.trd.2015.08.004 
Perera, L. P., Brage, M. (2016). Emission control based energy efficiency measures in ship operations. Applied Ocean Research. 60, pp. 29-46. https://doi.org/10.1016/j.apor.2016.08.006

Rehmatulla, N., Calleyab, J., Smitha, T. (2017). The implementation of technical energy efficiency and $\mathrm{CO} 2$ emission reduction measures in shipping. Ocean Engineering. 139, pp. 184-197. https://doi.org/10.1016/j.oceaneng.2017.04.029

Rolls-Royce products. [Online]. Available from: https://www.rolls-royce.com/ products-and-services/marine/product-finder/diesel-and-gas-engines.aspx\#section-product-search [Accessed: 10th November 2017]

Sheng, D., Li, Z. C., Fu, X., Gillen, D. (2017). Modeling the effects of unilateral and uniform emission regulations under shipping company and port competition. Transportation Research Part E: Logistics and Transportation Review. 101, pp. 99-114.

https://doi.org/10.1016/j.tre.2017.03.004

Stues-Lauridsen, F., Nielsen, J. B., Odgaard, T., Birkeland, M., Graugaard, C. W., Blikom, L. P., Muro-Sune, N., Andersen, M., Øvlisen, F. (2010).Natural gas for ship propulsion in Denmark - possibilities for using LNG and CNG on ferry and cargo routes. Envirinmental, Project 1338 2010, pp. 138. [Online]. Available from: http://aapa.files.cms-plus.com/PDFs/Danish\%20 Study.pdf\#page $=8 \& z o o m=90,0,-193$ [Accessed: 10 th November 2017]

Thomson, H., Corbett, J. J., Winebrake, J. J. (2015). Natural gas as a marine fuel. Energy Policy. 87, pp. 153-167.

https://doi.org/10.1016/j.enpol.2015.08.027
Wartsila (2015). Wärtsilä low-speed engines NOx- Emission - Tier 111 solutions INTERTANKO Annual Event Technical Workshop - Air Emissions NOx Tier 111 Athens. [Online]. Available from: http://www.intertanko.com/ Global/presentations/2015/Intertanko_W\%C3\%A4rtsi1\%C3\%A4_lowspeed_engine_Tier3.pdf [Accessed: 10th November 2017]

Weichai Heavy Machinery Dual-fuel Engine. [Online]. Available from: http:// www.weichaihm.com/en/index.php? $\mathrm{m}=$ content $\& \mathrm{c}=$ index $\& \mathrm{a}=$ lists \& catid $=127$ [Accessed: 10th November 2017]

Wik, C., Niemi, S. (2016). Low emission engine technologies for future tier 3 legislations - options and case studies. Journal of Shipping and Trade. 1(3), p. 22. https://doi.org/10.1186/s41072-016-0009-z

Wingd. Winterthur gas and diesel products. [Online]. Available from: https:// www.wingd.com/en/products/ [Accessed: 10th November 2017]

Yanmar products. URL: https://www.yanmar.com/us/news/2016/07/26/16510. html [Accessed: 10th November 2017]

Yoo, B. Y. (2017). Economic assessment of liquefied natural gas (LNG) as a marine fuel for $\mathrm{CO} 2$ carriers compared to marine gas oil (MGO). Energy. 121, pp. $772-780$.

https://doi.org/10.1016/j.energy.2017.01.061 